\title{
JURNA.L

\section{Pengaruh Orientasi Pasar, Inovasi dan Orientasi Kewirausahaan Terhadap Keunggulan Bersaing Pada UKM Di Jalanan Kota Kediri}

\section{(The Influence of Market Orientation, Innovation and Entrepreneurship Orientation on Competitive Advantage in SMEs on the Streets of Kediri City)}

\author{
Afif Nur Rahmadi', Tontowi Jauhari' ${ }^{2}$, Bothy Dewandaru ${ }^{3}$
}

${ }^{1}$ Prodi Manajemen Fakultas Ekonomi, ${ }^{2}$ Prodi Analisis Kesehatan Fakultas Ilmu

Kesehatan ${ }^{3}$ Prodi Ekonomi Pembangunan Fakultas Ekonomi

1afifnur@unik-kediri.ac.id, 2tontowi@unik-kediri.ac.id, ${ }^{3}$ bothy@unik-kediri.ac.id

\section{Info Artikel}

Diterima Agustus 1, 2020

Direvisi Agustus 20, 2020

Dipubikasi September 20, 2020

\section{Kata Kunci:}

Orientasi pasar, inovasi, orientasi kewirausahaan dan keunggulan bersaing

Keywords :

Market orientation, innovation, entrepreneurial orientation and competitive advantage

\begin{abstract}
Abstrak
Penelitian ini bertujuan untuk mengetahui pengaruh orientasi pasar, inovasi dan orientasi kewirausahaan terhadap keunggulan bersaing secara parsial dan simultan. Populasi dalam penelitian ini adalah pengusaha UKM yang berjualan di jalanan Erlangga dan Hayam Wuruk Kota Kediri, dengan jumlah sampel sekitar 96 responden. Berdasarkan hasil analisis data dan pembahasan dapat ditarik kesimpulan bahwa secara parsial orientasi pasar dan orientasi kewirausahaan berpengaruh posite dengan nilai paling tinggi atau dominan adalah orientasi pasar. Sedangkan inovasi berpengaruh negative terhadap keunggulan bersaing. Secara simultan orientasi pasar, inovasi dan orientasi kewirausahaan secara bersama-sama mempengaruhi keunggulan bersaing. Ini sangat baik, dengan meningkatkan orientasi pasar dan orientasi kewirausahaan maka keunggulan bersaing perusahaan akan juga meningkat. Oleh sebab itu, variabel orientasi pasar dan orientasi kewirausahaan selalu ditingkatkan.
\end{abstract}




\section{PENDAHULUAN}

Usaha Kecil Menengah (UKM) mempunyai kontribusi yang penting dalam membantu meningkatkan pendapatan daerah. UKM lebih fleksibel dan dapat membantu pemerintah dalam menciptakan lapangan pekerjaan. Perubahan yang terjadi dalam berbagai sektor seperti teknologi, menuntut UKM harus bisa beradaptasi dengan cepat agar tidak ketinggalan dengan perusahaan-perusahaan lain. Sebuah perusahaan dituntut mempunyai strategi bisnis agar bisa berkembang dan dapat menjaga eksistensi usahanya karena persaingan semakin ketat. Setiap perusahaan dituntut untuk melakukan perbaikan berkelanjutan baik dari segi produk maupun pelayanan, yang bertujuan untuk mendorong pertumbuhan pasar dan dapat memenangkan persaingan (Frengky Andiyanto and Sufian, Miyasto 2017).

Dilihat dari karakter Usaha Kecil dan Menengah (UKM) muncul persaingan usaha yang ketat, sehingga usaha kecil dituntut untuk mampu melakukan proses manajemen usaha yang produktif dan seefisien mungkin, serta dapat menghasilkan produk atau jasa yang sesuai dengan preferensi pasar dengan standar kualitas yang lebih baik dibandingkan dengan pesaing. Usaha kecil tidak cukup hanya memiiki keunggulan bersaing, usaha kecil dituntut pula untuk menghasilkan produk yang memiliki daya saing yang tinggi antara lain dengan kriteria: (1) Produk yang dijual tersedia secara teratur dan sinambung, (2) produk yang dijual harus memiliki kualitas yang baik dan seragam, (3) variasi produk harus dapat disediakan sesuai dengan kebutuhan dan permintaan pasar (Jayaningrum and Sanawiri 2018).

Orientasi pasar adalah suatu konsep multidimensional dimana konsep ini dapat dirumuskan melalui konsep: orientasi pelanggan, orientasi pesaing, dan koordinasi lintasfungsi (Fatah 2013). Sedangkan (Kohli and Jaworski 1990) mengatakan bahwa orientasi pasar merupakan budaya perusahaan yang bisa membawa pada meningkatnya kinerja pemasaran. Orientasi pasar didasarkan pada pertimbangan tertentu yang 
mengklasifikasikan bahwa konsep bukan tanggung jawab atas perhatian fungsi pemasaran, namun semua departemen berpartisipasi dalam pengumpulan, penyebaraluasan dan penindaklanjutan inlelijensi pasar (Tjiptono and Chandra 2008). Orientasi pasar sebagai budaya organisasi yang paling efektif dan efisien untuk menciptakan perilaku-perilaku yang dibutuhkan untuk menciptakan superior value bagi pembeli dan menghasilkan superior performance bagi perusahaan, apalagi dalam lingkungan yang bersaing ketat (Narver and Slater 1990). Lebih lanjut bahwa perusahaan yang telah menjadikan orientasi pasar sebagai budaya organisasi akan berfokus pada kebutuhan pasar eksternal, keinginan dan permintaan pasar sebagai basis dalam penyusunan strategi bagi masing-masing unit bisnis dalam organisasi, dan menentukan keberhasilan perusahaan (Slater and Narver 1995).

Kemampuan untuk meningkatkan kreativitas dalam menemukan ide-ide baru dan unik dibutuhkan untuk bersaing di pasar global. Keunggulan kompetitif menunjukkan bahwa perusahaan bertindak lebih baik daripada pesaing dalam hal yang sama. Kreativitas dalam bentuk inovasi produk harus dilakukan secara berkelanjutan sesuai dengan kebutuhan konsumen. Keberhasilan industri kreatif mengembangkan produk yang berorientasi pasar, kreativitas dan inovasi diharapkan dapat menciptakan keunggulan bersaing. Inovasi bisa menjadi faktor penentu keberhasilan dalam mencapai keunggulan kompetitif yang berkelanjutan. Lingkungan bisnis yang berubah mendorong persaingan yang ketat antar perusahaan di pasar global. Hal tersebut memotivasi perusahaan untuk memiliki strategi inovasi dalam memenangkan persaingan pasar global. Bagi industri kreatif, inovasi yang berorientasi pada konsumen merupakan solusi untuk bertahan dan siap menghadapi tantangan bisnis global. Kesadaran manajemen untuk berinovasi mendorong pertumbuhan perusahaan yang berkelanjutan (Sutapa, Mulyana, and Wasitowati 2018).

Orientasi kewirausahaan disebut-sebut sebagai spearhead (pelopor) untuk mewujudkan pertumbuhan ekonomi perusahaan berkelanjutan dan berdaya saing tinggi. Perusahaan yang berorientasi kewirausahaan akan selalu berupaya menghasilkan produkproduk baru yang inovatif dan memiliki keberanian untuk menghadapi resiko (Becherer 
and Maurer 1998). Orientasi kewirausahaan dan strategi bisnis dipandang memiliki kemampuan untuk meningkatkan kinerja sebuah perusahaan. Porter (1990) mendefinisikan orientasi kewirausahaan sebagai strategi benefit perusahaan untuk dapat berkompetisi secara lebih efektif di dalam market place yang sama. Orientasi kewirausahaan mengacu pada proses, praktik, dan pengambilan keputusan yangmendorong ke arah input baru dan mempunyai tiga aspek kewirausahaan, yaitu selalu inovatif, bertindak secara proaktif dan berani mengambil risiko (Lumpkin and Dess 1996). Dari beberapa penelitian menghasilkan bahwa orientasi pasar berpengaruh positif dan signifikan terhadap keunggulan bersaing secara langsung dan menjelaskan perkembangan pasar yang diinformasikan dari hasil deskripsi statistic pada penelitiannya, data orientasi pasar masih perlu ditingkatkan melalui riset pasar untuk menentukan posisi perusahaan, segmen pasar, target pasar, sehingga perusahaan bisa menciptakan peluang mendapatkan keungulan dalam bersaing (Haryono and Marniyati 2017). Penelitian yang lain menunjukkan orientasi pasar serta inovasi berpengaruh positif dan signifikan terhadap keunggulan kompetitif. Hal ini menunjukkan bahwa orientasi pasar yang telah dilakukan perusahaan dapat berpengaruh secara langsung dalam menciptakan keunggulan kompetitif. Para pemilik atau pengelola IKM furniture di Kota Gianyar sudah menyadari bahwa hanya usaha yang melakukan orientasi pasar yang dapat bertahan di tengah persaingan yang ada, karena produknya memiliki keunggulan kompetitif di benak pelanggan (Ketut et al. 2018).

Penelitian (Talaja et al. 2017) menemukan bahwa orientasi pasar berpengaruh positif secara signifikan terhadap keunggulan bersaing. Demikian pula dengan penelitian oleh (Dalimunthe 2017) menjelaskan bahwa terdapat pengaruh langsung dan positif secara signifikan antara orientasi pasar terhadap keunggulan bersaing. Temuan penelitian ini menunjukkan bahwa variabel orientasi pasar, dimana dalam penelitian ini lebih ditekankan pada value utama perusahaan, segmentasi pasar, pemenuhan kebutuhan, keinginan pelanggan, orientasi pelanggan dan pesaing serta koordinasi lintas fungsi memberikan pengaruh positif terhadap keunggulan bersaing (Alwi and Handayani 2018). Hasil penelitian berikutnya menunjukkan bahwa ada pengaruh yang positif antara orientasi kewirausahaan terhadap keunggulan bersaing UMKM industri pangan di Kota 
Bengkulu, berupa: dimilikinya sikap inovatif, proaktif, dan berani mengambil risiko (Studi et al. 2016).

Dari uraian beberapa penelitian diatas serta dalam kondisi pandemik dan kebijakan pemerintah saat ini, ketahanan UKM saat ini diuji dengan orientasi pasar, inovasi dan orientasi kewirausahaan yang dimilikinya. Setiap konsumen itu sendiri memiliki perilaku yang berbeda dalam pembelian. Oleh sebab itu perbedaaan kebutuhan dan keinginan yang ada di konsumen memnimbulkan perilaku pembelian yang unik. Kota Kediri juga merupakan salah satu kota yang berhasil menciptakan dan menggali potensi masyarakatnya untuk memunculkan potensi, sehingga mampu meningkatkan pendapatan daerahnya.

Dari latar belakang diatas maka penelitian ini memiliki tujuan yaitu ingin mengetahui pengaruh orientasi pasar, inovasi, orientasi kewirausahaan terhadap keunggulan bersaing pada UKM di jalanan Kota Kediri secara parsial dan, ingin mengetahui pengaruh orientasi pasar, inovasi, orientasi kewirausahaan terhadap keunggulan bersaing pada UKM di jalanan Kota Kediri secara sumultan.

\section{METODE PENELITIAN}

Metode yang digunakan dalam penelitian ini adalah metode penelitian kuantitatif. Populasi dalam penelitian ini adalah pengusaha UKM yang ada di jalan Erlangga dan Hayam Wuruk Kota Kediri sejumlah 96 responden. Teknik pengumpulan data menggunakan probability sampling (Sugiyono 2010). Dalam memperoleh data dari responden digunakan wawancara, studi pustaka, observasi serta membagikan kuesioner yang disusun berdasarkan indikator dari masing-masing variabel menggunakan skala pengukuran likert 1-5. Dari data yang terkumpul kemudian dilakukan analisis data menggunakan program SPSS (Statistical Package for Social Science). Analisis ini dilakukan dengan beberapa tahapan analisis regresi Linear berganda adalah suatu alat analisis peramalan nilai pengaruh dua variabel bebas atau lebih terhadap variabel terikat untuk membuktikan ada atau tidaknya hubungan fungsi atau hubungan kausal antara dua variabel bebas atau lebih dengan satu variabel terikat (Sugiyono 2015). Tujuan dari alat 
analisis ini adalah untuk mengetahui besarnya pengaruh yang ditimbulkan antara orientasi pasar, inovasi dan orientasi kewirausahaan terhadap keunggulan bersaing menggunakan persamaan regresi berganda. Selanjutnya Uji Hipotesis menggunakan Uji t dan Uji f.

\section{HASIL DAN PEMBAHASAN}

Penelitian ini menggunakan 96 responden yang diambil dari pengusaha UKM yang berjualan tetap di sepanjang jalan Erlangga dan Hayam Wuruk Kota Kediri baik yang jualan pada siang dan malam hari. Penelitian ini dilakukan pada saat bulan Juli sampai dengan Agustus Tahun 2020. Hasil uji validitas dari penelitian ini menunjukkan bahwa hasil kuesioner dari variabel orientasi pasar, inovasi, orientasi kewirausahaan terhadap keunggulan bersaing dinyatakan valid.

Tabel 1. Hasil Uji Validitas

\begin{tabular}{lcc|ccc}
\hline Item & R.hitung & R.tabel & Item & R.hitung & R.tabel \\
\hline $\mathrm{X} 1.1$ & 0.446 & 0.202 & $\mathrm{X} 3.1$ & 0.701 & 0.202 \\
$\mathrm{X} 1.2$ & 0.301 & 0.202 & $\mathrm{X} 3.2$ & 0.454 & 0.202 \\
$\mathrm{X} 1.3$ & 0.737 & 0.202 & $\mathrm{X} 3.3$ & 0.367 & 0.202 \\
$\mathrm{X} 1.4$ & 0.737 & 0.202 & $\mathrm{X} 3.4$ & 0.727 & 0.202 \\
$\mathrm{X} 1.5$ & 0.597 & 0.202 & $\mathrm{X} 3.5$ & 0.737 & 0.202 \\
$\mathrm{X} 1.6$ & 0.732 & 0.202 & $\mathrm{Y} 1.1$ & 0.479 & 0.202 \\
$\mathrm{X} 1.7$ & 0.71 & 0.202 & $\mathrm{Y} 1.2$ & 0.921 & 0.202 \\
$\mathrm{X} 2.1$ & 0.424 & 0.202 & $\mathrm{Y} 1.3$ & 0.883 & 0.202 \\
$\mathrm{X} 2.2$ & 0.416 & 0.202 & $\mathrm{Y} 1.4$ & 0.883 & 0.202 \\
$\mathrm{X} 2.3$ & 0.636 & 0.202 & $\mathrm{Y} 1.5$ & 0.658 & 0.202 \\
$\mathrm{X} 2.4$ & 0.772 & 0.202 & $\mathrm{Y} 1.6$ & 0.479 & 0.202 \\
$\mathrm{X} 2.5$ & 0.567 & 0.202 & $\mathrm{Y} 1.7$ & 0.921 & 0.202 \\
$\mathrm{X} 2.6$ & 0.41 & 0.202 & $\mathrm{Y} 1.8$ & 0.883 & 0.202 \\
\hline
\end{tabular}

Selanjutnya uji reliabelitas dari semua item pertanyaan dari kuesioner yang disajikan kepada responden cukup besar dimana koefisien alpha diatas 0,60 sehingga dapat dikatakan semua konsep pengukuran dari kuesioner adalah realibel.

Tabel 2. Hasil Uji Reliabelitas

Reliability Statistics 


\begin{tabular}{cc}
\hline $\begin{array}{c}\text { Cronbach's } \\
\text { Alpha }\end{array}$ & N of Items \\
\hline .822 & 26 \\
\hline
\end{tabular}

Pengolahan data yang telah didapat dan diuji dengan menggunakan regresi linier berganda, selanjutnya dilakukan beberapa tahapan dimana semua variabel dimasukkan untuk mecari pengaruh variabel independent terhadap variabel dependent. Dimana variabel independent disini orietasi pasar, inovasi dan orientasi kewirausahaan. Dan variebel dependent dalam penelitian ini yaitu keunggulan bersaing. Adapun hasil uji regresi berganda penelitian ini sebagai berikut:

\section{Tabel.3 Hasil Uji Regresi Berganda}

\begin{tabular}{|c|c|c|c|c|c|c|}
\hline \multicolumn{7}{|c|}{ Coefficients $^{a}$} \\
\hline & \multirow[b]{2}{*}{ Model } & \multicolumn{2}{|c|}{ Unstandardized Coefficients } & \multirow{2}{*}{$\begin{array}{c}\text { Coefficients } \\
\text { Beta }\end{array}$} & \multirow[b]{2}{*}{$\mathrm{T}$} & \multirow[b]{2}{*}{ Sig. } \\
\hline & & $\mathrm{B}$ & Std. Error & & & \\
\hline 1 & (Constant) & 12.448 & 2.751 & & 4.524 & .000 \\
\hline & $\mathrm{X} 1$ & .662 & .128 & .590 & 5.166 & .000 \\
\hline & X2 & -.165 & .074 & -.166 & -2.243 & .027 \\
\hline & X3 & .338 & .165 & .226 & 2.052 & .043 \\
\hline
\end{tabular}

a. Dependent Variable: Y

Sehingga dapat diperoleh nilai koefisien regresi berganda yang mana muncul sebuah persamaan $\mathrm{Y}=12.448+0.662 \mathrm{X}_{1}+(-0.165) \mathrm{X}_{2}+0.338 \mathrm{X}_{3}+\mathrm{e}$.

Dari persamaan tersebut diatas maka dapat diinterprestasikan bahwa, konstanta $\alpha$ $=12.448$ artinya apabila tidak ada perubahan pada orientasi pasar, inovasi dan orientasi kewirausahaan terhadap keunggulan bersaing, maka variabel keunggulan bersaing akan meningkat sebesar 12.448 satuan. Jika variabel orientasi pasar naik sebanyak satu satuan, keunggulan bersaing akan meningkat sebesar 0.662 satuan. Berikutnya apabila inovasi naik sebanyak satu satuan, keunggulan bersaing akan meningkat sebesar -0.165 satuan. Sedangkan apabila orientasi kewirausahaan naik sebanyak satu satuan, maka keunggulan bersaing akan meningkat 0.338 satuan.

Pengujian hipotesis dalam penelitian ini dilihat dari pengujian secara parsial atau uji $\mathrm{t}$ dapat ditarik kesimpulan variabel yang terdiri dari orientasi pasar dan orientasi 
kewirausahaan berpengaruh positif secara parsial terhadap keunggulan bersaing dan variabel inovasi berpengaruh negatitif terhadap keunggulan bersaing. Serta uji f menghasilkan bahwa orientasi pasar, inovasi dan orientasi kewirausahaan berpengaruh secara simultan terhadap keunggulan bersaingpada usaha UKM di jalan Erlangga dan Hayam Wuruk Kota Kediri.

\section{Pengaruh orientasi pasar terhadap keunggulan bersaing}

Nilai koefisien regresi orientasi pasar dimana b1 sebesar 0.662 pada persamaan regresi linear berganda menunujukkan bahwa orientasi pasar mempunyai pengaruh positif pada keunggulan bersaing. Sehingga artinya semakin tinggi nilai kebijakan pengusaha terhadap orientasi pasar, maka akan berpengaruh lebih besar atau tinggi keunggulan bersaingnya.

Penelitian ini tidak didukung oleh penelitian (Sumiati 2015) bahwa orientasi pasar tidak berpengaruh terhadap keunggulan bersaing. Namun penelitian ini mendukung penelitian sebelumnya dari (Alwi and Handayani 2018) bahwa orientasi pasar berpengaruh positif terhadap variabel keunggulan bersaing, semakin tinggi orientasi pasar maka semakin tinggi pula keunggulan bersaing.

Penelitian ini menunjukkan bahwa variabel orientasi pasar yang terdiri dari orientasi pelanggan, orientasi pesaing dan informasi pasar memberikan pengaruh positif terhadap keunggulan bersaing.

\section{Pengaruh inovasi terhadap keunggulan bersaing}

Nilai koefisien regresi inovasi dimana b2 sebesar -0.165 pada persamaan regresi linear berganda menunujukkan bahwa inovasi mempunyai pengaruh negatif pada keunggulan bersaing. Sehingga artinya semakin tinggi nilai kebijakan pengusaha terhadap inovasi, maka akan berpengaruh negatif terhadap keunggulan bersaing. Dalam kondisi pandemik seperti ini pengusaha merasa ditingkatkannya inovasi terhadap produk tidak akan mengalami perubahan terhadap keunggulan bersaing, dimana inovasi yang dilakukan oleh pengusaha akan mengeluarkan biaya tambahan yang besar. Akan tetapi, minat pembeli saat pandemik seperti menurun.

Penelitian ini tidak didukung oleh penelitian (Alwi and Handayani 2018) bahwa inovasi berpengaruh terhadap keunggulan bersaing. Penetian ini didukung juga oleh 
(Haryono and Marniyati 2017) yang menunjukan inovasi berpengaruh positif terhadap keunggulan bersaing. Hasil penelitian ini menunjukkan bahwa variabel inovasi yang terdiri dari penemuan pengembangan, dan duplikasi berpengaruh negatif terhadap keunggulan bersaing.

\section{Pengaruh orientasi kewirausahaan terhadap keunggulan bersaing}

Nilai koefisien regresi orientasi kewirausahaan dimana b3 sebesar 0.338 pada persamaan regresi linear berganda menunujukkan bahwa orientasi kewirausahaan mempunyai pengaruh positif terhadap keunggulan bersaing. Sehingga artinya semakin tinggi nilai kebijakan pengusaha terhadap orientasi kewirausahaan, maka akan berpengaruh pengaruh terhadap keunggulan bersaing. Penelitian ini tidak didukung oleh penelitian (Fatmawati 2016) bahwa orientasi kewirausahaan berpengaruh positif terhadap keunggulan bersaing. Penetian ini didukung juga oleh (Jayaningrum and Sanawiri 2018) yang menunjukan orientasi kewirausahaan berpengaruh positif terhadap keunggulan bersaing. Hasil penelitian ini menunjukkan bahwa variabel orientasi kewirausahaan yang terdiri dari berani mengambil risiko, membuat produk sesuai dengan keinginan pelanggan, kemampuan pengusaha dalam menanggulangi dan mengintasipasi segala perubahan, kemampuan untuk mengenali peluang dan komitmen untuk inovasi dan kreativitas memperkenalkan produk berpengaruh positif terhadap keunggulan bersaing.

\section{KESIMPULAN DAN SARAN}

Penelitian ini dapat disimpulkan bahwa ada pengaruh positif antara orientasi pasar dan orientasi kewirausahaan terhadap keunggulan bersaing secara parsial. Sedangkan variabel inovasi secara parsial berpengaruh negative terhadap keunggulan bersaing. Serta berpengaruh secara simultan orientasi pasar, inovasi dan orientasi kewirausahaan terhadap keunggulan bersaing. Penelitian ini didukung oleh penelitian sebelumnya dari (Jayaningrum and Sanawiri 2018) dan penelitian (Fatmawati 2016) bahwa secara simultan orientasi pasar, inovasi dan orientasi kewirausahaan berpengaruh terhadap keunggulan bersaing. Saran dari penelitian ini bahwa ada model alat analisa lain selanjutnya sampel diperbanyak dan memperluas objek penelitian.

\section{UCAPAN TERIMA KASIH}




\section{JURNAL

Penelitian ini dihasilkan karena mendapatkan bantuan dari pemerintah dengan program Hibah SIMLITABMAS dengan skema Penelitian Dosen Pemula (PDP) dan semoga penelitian bisa bermanfaat khusunya dalam pengembangan ilmu di Universitas Kadiri.

\section{DAFTAR PUSTAKA}

Alwi, Taufik and Esti Handayani. 2018. "Keunggulan Bersaing Ukm Yang Dipengaruhi Oleh Orientasi Pasar Dan Inovasi Produk." (April).

Becherer, Richard C. and John G. Maurer. 1998. "E ] P." 47-58.

Dalimunthe, Muhammad Bukhori. 2017. "KEUNGGULAN BERSAING MELALUI ORIENTASI PASAR DAN INOVASI PRODUK." 3(1):18-31.

Fatah, Ahmad Vian Abdul. 2013. "Effect of Product Innovation and Competitive Advantage of Market Orientation ( Survey on Deden." Repository UNIKOM.

Fatmawati, Rossa Amalia. 2016. "PENGARUH ORIENTASI PASAR, ORIENTASI KEWIRAUSAHAAN TERHADAP KEUNGGULAN BERSAING DAN KINERJA PEMASARAN Pada Warung Kucingan/Angkringan Di Kota Semarang." Jurnal Ilmu Administrasi Bisnis volume 5,.

Frengky Andiyanto and Syuhada Sufian, Miyasto. 2017. "Analisis Pengaruh Orientasi

Pasar Dan Inovasi Terhadap Keunggulan Bersaing Dalam Rangka Meningkatkan Kinerja Bisnis (Studi Empiris Pada Industri Pakaian Jadi Skala Kecil Dan Menengah Di Kabupaten Kudus) Frenky." 1-20.

Haryono, Tulus and Sabar Marniyati. 2017. "Pengaruh Market Orientation, Inovasi

Produk, Dan Kualitas Produk Terhadap Kinerja Bisnis Dalam Menciptakan

Keunggulan Bersaing.” Jurnal Bisnis \& Manajemen 17(2):51-68.

Jayaningrum, Erni and Brillyanes Sanawiri. 2018. "Pengaruh Orientasi Pasar, Inovasi, Orientasi Kewirausahaan Terhadap Keunggulan Bersaing Dan Kinerja Pemasaran (Studi Pada Kuliner Kafe Kota Malang) Erni." 54(1):149-58.

Ketut, Ni, Pertiwi Satwika, Ni Made, Wulandari Kusuma, and Asean Free. 2018.

"Pengaruh Orientasi Pasar Serta Inovasi Terhadap Keunggulan Kompetitif Dan Kinerja Bisnis." 7(3):1481-1509.

Kohli, Ajay K. and Bernard J. Jaworski. 1990. "Market Orientation : The.” 54(April):118.

Lumpkin, G. .. and Gregory G. Dess. 1996. "THE ENTREPRENEURIAL

CLARIFYING IT CONSTRUCT AND LINKING ORIENTATION.”'Academy of Management Review 21(1):135-72.

Narver, John C. and Stanley F. Slater. 1990. "The Effect of a Market Orientation on

Business Profitability.” Journal of Marketing 54(4):20-35.

Slater, Stanley F. and John C. Narver. 1995. "Market Orientation and the Learning Organization.” Journal of Marketing 59(3):63-74.

Studi, Program, Teknologi Pertanian, Fakultas Pertanian, and Universitas Dehasen. 2016. "PENGARUH ORIENTASI KEWIRAUSAHAAN DAN MANAJEMEN KUALITAS TERHADAP KEUNGGULAN BERSAING USAHA MIKRO, KECIL DAN MENENGAH (UMKM) INDUSTRI PANGAN DI KOTA 
BENGKULU." II(2).

Sugiyono. 2010. Sugiyono. Bandung: ALFABETA.

Sugiyono, P. D. 2015. "Metode Penelitian Dan Pengembangan.” Res. Dev. D 2015:3941.

Sumiati. 2015. "Pengaruh Strategi Orientasi Wirausaha Dan Orientasi Pasar

Pengaruhnya Terhadap Kinerja Perusahaan UMKM Di Kota Surabaya.” Jurnal

Ekonomi \& Manajemen 1(1):31-44.

Sutapa, Sutapa, Mulana Mulyana, and Wasitowati Wasitowati. 2018. "The Role of

Market Orientation, Creativity and Innovation in Creating Competitive Advantages and Creative Industry Performance.” Jurnal Dinamika Manajemen 8(2):152-66.

Talaja, Anita, Dario Miočević, Nikša Alfirević, and Jurica Pavičić. 2017. "Market

Orientation, Competitive Advantage and Business Performance: Exploring the Indirect Effects." Drustvena Istrazivanja 26(4).

Tjiptono, Fandy and Gregorius Chandra. 2008. "Manajemen Strategik." Andi Offset, Yogyakarta. 